\title{
Production of 5-hydroxy-7-methoxy-4-methylphthalide in a culture of Penicillium crustosum
}

\author{
ANGELA M.M.P. VALENTE ${ }^{1}$, ANTONIO G. FERREIRA ${ }^{2}$, CRISTINA DAOLIO $^{2}$, EDSON RODRIGUES FILHO $^{3}$, \\ ELISANGELA F. BOFFO ${ }^{4}$, ANTONIA Q.L. SOUZA ${ }^{5}$, FERNANDA L.S. SEBASTIANES ${ }^{6}$ and ITAMAR S. MELO ${ }^{1}$ \\ ${ }^{1}$ Laboratório de Microbiologia Ambiental, Embrapa Meio Ambiente (CNPMA), \\ Via SP 340, Km 127,5, Caixa Postal 69, 13820-000 Jaguariúna, SP, Brasil \\ ${ }^{2}$ Laboratório de Ressonância Magnética Nuclear and Laboratório de Microbiologia Molecular e Espectroscopia de Massas, \\ Departamento de Química, Universidade Federal de São Carlos (UFSCar), \\ Via Washington Luís, Km 235, Caixa Postal 676, 13565-905 São Carlos, SP, Brasil \\ ${ }^{3}$ Laboratório de Microbiologia Molecular e Espectroscopia de Massas, Departamento de Química, \\ Universidade Federal de São Carlos (UFSCar), Via Washington Luís, Km 235, \\ Caixa Postal 676, 13565-905 São Carlos, SP, Brasil \\ ${ }^{4}$ Departamento de Química Orgânica, Instituto de Química, Universidade Federal da Bahia (UFBA), \\ Rua Barão de Geremoabo, 147, Campus Universitário de Ondina, 40170-115 Salvador, BA, Brasil \\ ${ }^{5}$ Laboratório de Produtos de Origem Microbiana, Instituto de Ciências Biológicas/ ICB-DFCA, \\ Universidade Federal do Amazonas (UFAM), Av. General Rodrigo Octávio Jordão Ramos, 3000, \\ Campus Universitário, Coroado I, 69077-000 Manaus, AM, Brasil \\ ${ }^{6}$ Departamento de Genética, Escola Superior de Agricultura 'Luiz de Queiroz', Universidade de São Paulo (USP), \\ Avenida Pádua Dias, 11, Caixa Postal 83, 13400-970 Piracicaba, SP, Brasil
}

Manuscript received on February 12, 2012; accepted for publication on July 9, 2012

\begin{abstract}
The chemical reactions carried out by microorganisms have been used as a tool in modern chemistry. This paper reports the production of mycophenolic acid and a new phthalide by the endophytic fungus Penicillium crustosum obtained from coffee seeds. The fungus was cultivated in a liquid medium for a period of seven days and after that the culture medium was divided into four treatments: A, B, C and D, to which different organic substances were added. Treatment A was maintained as the control to evaluate the occurrence of biotransformation. Organic acids were added to the culture media of treatments B (ferulic and quinic acids) and $\mathrm{C}$ [cinnamic and 3,4-(methylenedioxy) cinnamic acids], and caffeine was added in the treatment D. All these organic compounds were dissolved in DMSO, and the fermentation was maintained for more 13 days, totalizing 20 days. Mycophenolic acid was isolated from the culture with no added acids (treatment A). Mycophenolic acid and a new phthalide, 5-hydroxy-7-methoxy-4-methylphthalide were isolated from treatments $\mathrm{B}$ and $\mathrm{C}$, and mycophenolic acid and caffeine (added to the culture medium) were isolated from treatment $\mathrm{D}$. The structures were determined by NMR techniques and confirmed by MS and MS/MS techniques.
\end{abstract}

Key words: coffee, Endophytic fungus, Mycophenolic acid, Penicillium crustosum, 5-hydroxy-7-methoxy4-methylphthalide.

Correspondence to: Angela M.M.P. Valente

E-mail: angvalente@gmail.com 


\section{INTRODUCTION}

The plant kingdom is colonized by a diversity of endophytic microorganisms, resulting in beneficial associations that can stimulate plant growth, and increased resistance to diseases and adverse environmental conditions. There are several studies showing that endophytes do not act alone or only at the level of the host, but rather in a complex network of interactions with the microbial flora and native plant metabolism (Silva et al. 2006).

The colonization of the host plant by endophytes may be mediated by interesting secondary metabolites of potential use to modern medicine, agriculture and industry (Strobel and Daisy 2003, Mitchell et al. 2008). Surveys of the endophytes have been carried out in dozens of plants of important agricultural commodities, but coffee has been practically unexplored (Vega et al. 2005). Various endophytic Penicillium species were isolated from Coffea arabica, including Penicillium crustosum. The role that these endophytes play in the biology of the coffee plant remains enigmatic, but the fact that no Penicillium species have been reported as pathogens of Coffea spp implies that these endophytes are not latent pathogens, suggesting either commensal or mutualistic relationships (Vega and Posada 2006).

The Penicillium genus is noted for producing a variety of bioactive metabolites possessing diverse biological properties including plant growth regulators (Arnold 2007)

Mycophenolic acid is produced by Byssochlamys nivea and mainly by several Penicillium species, such as $P$. brevi-compactum, $P$. roqueforti, $P$. roqueforti var. carneum, $P$. bialowiezense, $P$. chrysogenum, $P$. raciborkii, $P$. stoloniferum, and other Penicillium spp. It presents several biological activities, amongst which antibiotic activity, and it has also been successfully applied as an immunosuppressant after organ transplantation, administered in the form of the pro-drug Mycophenolate Mofetil (Grinyo 2001). Recently mycophenolic acid was obtained by the biotransformation of imbricatolic acid, obtained from a culture of Cunninghamella echinulata (Schmeda-Hirschmann et al. 2007).

The chemical reactions carried out by microorganisms have been used as a tool in modern chemistry, but the use of microorganisms in chemistry is not a new issue. Bacteria and fungi have been used to produce chemicals, pharmaceuticals and perfumes for decades. However their use for modifying the chemical structures of natural products is more recent, it is very well documented (Boaventura et al. 2004).

This study aimed to use the endophytic fungus Penicillium crustosum, isolated from coffee beans, to transform characteristic substances of the coffee, such as caffeine, cinnamic, ferulic and quinic acids, and 3,4-methylenedioxycinnamic acid, which is a semi-synthetic substance.

\section{MATERIALS AND METHODS}

SAMPLING

Apparently healthy coffee (Coffea arabica L.) fruits from ripe berries (crown, peduncle, pulp and seeds) were harvested from coffee plantations in Águas da Prata, Brazil and taken to the Laboratory of Molecular Microbiology and Mass Spectroscopy of the Chemistry Department at the Universidade Federal de São Carlos, where the fungus was isolated.

\section{FUNGAL ISOLATION}

Half of the coffee fruits were fragmented and the other half was dried in the sun, simulating the process of normal drying for subsequent storage. The fragments (peel, pulp and beans) were plated onto potato dextrose agar (PDA), and after drying in the sun for one week, the whole fruits were peeled and inoculated without cutting. Both the fruit fragments and the fruit peel (not cut) were 
sterilized by a series of immersions in the following order: $1 \mathrm{~min}$ in $70 \%$ ethanol, $4 \mathrm{~min}$ in $11 \%$ sodium hypochlorite, $0.5 \mathrm{~min}$ in $70 \%$ alcohol and $1 \mathrm{~min}$ in distilled water. The beans seeds were inoculated onto PDA contained in Petri dishes, and $0.1 \%$ stock antibiotic solution was then added (stock: $0.02 \mathrm{~g}$ streptomycin in $10 \mathrm{~mL}$ sterile distilled water, filter sterilized; from this $1 \mathrm{~mL}$ was added per liter of medium). The cultures were incubated at room temperature $\left(25^{\circ} \mathrm{C}\right)$.

\section{SCANNING ELECTRON MicrosCOPE}

The method used to prepare the material for scanning electron microscopy (SEM) was similar to the one described by Melo and Faull (2004). The samples were dried in a critical point (Dryer) (Emitech), sputtered (Emitech plating) with gold for 3 minutes at $30 \mathrm{~mA}$ and observed under a Field Emission Scanning Microscope (Gemini Leo 982 Zeiss + Leica) at the Environmental Microbiology Laboratory of the Brazilian Agriculture Research Corporation - Embrapa.

\section{STRAIN TAXONOMY}

The genomic DNA from the P. crustosum strain, Cat12.3, was extracted according to the method described by Raeder and Broda (1985). The fungi were identified by comparing the rDNA from the internal transcribed spacer (ITS) regions with sequences deposited in the GenBank. The ITS15.8S-ITS2 region was amplified by the polymerase chain reaction (PCR) using the ITS1 primer (5'-TCCGTAGGTGAACCTGCGG-3') and the ITS4 primer (5'-TCCTCCGCTTATTGATATGC-3') in a Peltier Thermal Cycler 200, MJ Research. The conditions for DNA amplification included an initial denaturation step of $5 \mathrm{~min}$ at $94^{\circ} \mathrm{C}$, followed by 24 cycles of $30 \mathrm{~s}$ at $94^{\circ} \mathrm{C}$ (denaturation), $30 \mathrm{~s}$ at $55^{\circ} \mathrm{C}$ (annealing) and $30 \mathrm{~s}$ at $72^{\circ} \mathrm{C}$ (elongation), plus a final elongation step of $7 \mathrm{~min}$ at $72^{\circ} \mathrm{C}$. The amplicons were purified using GFX columns (GE
Healthcare UK Ltd., Buckinghamshire, England), and then cycle-sequenced using the BigDye ${ }^{\circledR}$ Terminator Cycle Sequencing Kit (Applied Biosystems, Nieuwerkerk, The Netherlands). The PCR products were sequenced by using the same primers used for amplification. Each sequence was obtained in duplicate from each of two separate PCR amplifications. The ITS sequence of the strain found in this study matched the ITS sequence of Penicillium crustosum (GenBank Accession No. GU723443), and displayed 99\% similarity. The ITS sequence of the Penicillium crustosum isolated was aligned with different Penicillium isolates available in the GenBank nucleotide data base, using the MEGA 4.0 program (Tamura et al. 2007). The phylogenetic analysis was carried out by a neighbor-joining method to infer the relationships between the Penicillium crustosum isolate and sequences available for Penicillium in the GenBank. For this analysis, 1,000 bootstrap replicates were carried out to assess the statistical support for each tree. The fungus was deposited and preserved in the collection of the Environmental Microbiology Laboratory of the Brazilian Agriculture Research Corporation - Embrapa.

\section{Culture (Fungus CATL2.3)}

After five days of growth, 3 - 5 pieces of the PDA culture containing mycelium, each $5 \mathrm{~mm}$ in diameter, were inoculated into 40 Erlenmeyer flasks (500 $\mathrm{mL}$ ) containing $250 \mathrm{~mL}$ of the following medium: $3.0 \mathrm{~g} \mathrm{NaNO}_{3}, 1.0 \mathrm{~g} \mathrm{~K}_{2} \mathrm{HPO}_{4}, 0.5 \mathrm{~g} \mathrm{MgSO}_{4} .7 \mathrm{H}_{2} \mathrm{O}$, $0.5 \mathrm{~g} \mathrm{KCl}, 0.01 \mathrm{~g} \mathrm{FeSO}_{4} .7 \mathrm{H}_{2} \mathrm{O}, 10.0 \mathrm{~g}$ glucose, and $8.0 \mathrm{~g}$ yeast extract in 1.0 liter of distilled water. This culture was autoclaved for 15 minutes at $120^{\circ} \mathrm{C}$ and incubated at room temperature $\left(28^{\circ} \mathrm{C}\right)$ in the static mode for seven days.

On the seventh day, 10 flasks were maintained as the control (A), $1 \mathrm{~mL}$ of quinic plus ferulic acids added to another 10 flasks (B), $1 \mathrm{~mL}$ cinnamic acid plus methylenedioxycinnamic acid to another 10 
(C) and $2 \mathrm{~mL}$ of caffeine added to the final 10 (D). These solutions were sterilized using Millipore filters, and the cultivation continued for 13 days in the static mode.

\section{EXTRACTION, PURIFICATION AND ISOLATION}

After 20 days of fermentation, $350 \mathrm{~mL}$ of $\mathrm{CH}_{2} \mathrm{Cl}_{2} /$ $\mathrm{MeOH}(7: 3 \mathrm{v} / \mathrm{v})$ were added to each flask and the flasks allowed to rest for 24 hours. The mycelium was then separated from the culture medium, the organic and aqueous phases separated from each other, and the aqueous phase partitioned twice with dichloromethane. The dried organic extracts [A (338.4 mg), B (524.3 mg), C (537.7 mg) and D (964.0 mg)] were fractionated by CC over common silica (with vacuum) using a gradient elution system $\left[n-\mathrm{C}_{6} \mathrm{H}_{14} /\right.$ EtOAc $(10: 0,7: 3 ; 5: 5 ; 4: 6,0: 10$ $\mathrm{v} / \mathrm{v})$ and $\mathrm{EtOAc} / \mathrm{MeOH}(9: 1,8: 2,6: 4,4: 6,2: 8$ and $0: 10 \mathrm{v} / \mathrm{v})]$.

Very pure mycophenolic acid was isolated from extract A (fraction 5, $100 \%$ EtOAc).

Fractions 5 and 6 from extract B (100\% EtOAc and EtOAc/MeOH 9:1, respectively) were mixed together [154.5 mg], re-chromatographed on Sephadex LH-20 (2.5 cm - diameter x $64.0 \mathrm{~cm}$ - length) and eluted in $\mathrm{MeOH} / \mathrm{CH}_{3} \mathrm{OCH}_{3}$ (8:2 and 10:0 v/v). Mycophenolic acid was isolated from subfractions 4, 5 and $6\left(\mathrm{MeOH} / \mathrm{CH}_{3} \mathrm{OCH}_{3}, 8: 2\right.$ $\mathrm{v} / \mathrm{v}$ ), and 5-hydroxy-7-methoxy-4-methylphthalide was isolated from subfractions 7, 8 and 9, eluted in $\mathrm{MeOH}(100 \%)$.

Fractions 5, 6 and 7 from extract C (100\% EtOAc, EtOAc/MeOH - 9:1 and EtOAc/MeOH - 8:2, respectively) were mixed [270.6 $\mathrm{mg}$ ] and chromatographed under the same conditions as extract B. Mycophenolic acid and 5-hydroxy-7methoxy-4-methylphthalide were again isolated.

Fractions 4 and 5 from extract D (100\% EtOAc and EtOAc/MeOH - 9:1, respectively) were mixed [141.5 mg] and subjected to column chromatography on flash-type silica gel $(3.0 \mathrm{~cm} \mathrm{x}$
$24.5 \mathrm{~cm}$ ), and eluted in a gradient system: EtOAc/ Hex 8:2; EtOAc/Hex 9:1; EtOAc 100\%; EtOAc/ $\mathrm{MeOH}$ 9:1; EtOAc/MeOH 1:1 and $\mathrm{MeOH}$ 100\%. All the fractions were analyzed by TLC, and the caffeine was isolated from the fractions eluted in EtOAc (100\%). Fraction 6 from extract D was subjected to preparative-layer chromatography (PLC), eluted with $\mathrm{CH}_{2} \mathrm{Cl}_{2} / \mathrm{CH}_{3} \mathrm{OCH}_{3}$ (7:3), and six subfractions obtained $(\mathrm{a}-\mathrm{g})$. Mycophenolic acid was obtained in fraction $6 \mathrm{a}$.

NMR DATA

All the NMR data were recorded at $298 \mathrm{~K}$ using a Bruker DRX400 spectrometer operating at $9.4 \mathrm{~T}\left({ }^{1} \mathrm{H}\right.$ at 400.2 and ${ }^{13} \mathrm{C}$ at $\left.100.6 \mathrm{MHz}\right)$. Tetramethylsilane (TMS) was employed as the internal reference for chemical shifts $(\delta 0.0$ ppm). Mycophenolic acid was dissolved in 600 $\mu \mathrm{L}$ of $\mathrm{CDCl} 3$ and 5-hydroxy-7-methoxy-4methylphthalide in $600 \mu \mathrm{L}$ of DMSO- $\mathrm{d}_{6} \cdot{ }^{1} \mathrm{H},{ }^{13} \mathrm{C}$, $g H S Q C$ and $g$ HMBC NMR spectra were acquired using standard pulse sequences. The TopSpin software was used for data processing.

\section{MASS SPECTROSCOPY DATA}

Low-resolution ESI-MS and ESI-MS/MS data were acquired in the negative and positive ion modes, using a QuattroLC mass spectrometer (Micromass, triple-quadrupole, ESI/APCI). Mycophenolic acid and 5-hydroxy-7-methoxy-4-methylphthalide, dissolved in methanol, were constantly introduced by direct infusion using the equipment syringe pump at $5 \mathrm{~mL} \cdot \mathrm{min}^{-1}$. The Masslynx 3.5 software was used for data processing.

\section{RESULTS AND DISCUSSION}

From 175 fragments of fresh fruits including pulp, skin and seeds, 64 strains of endophytic fungi were isolated. However, only one endophytic fungus (Cat12.3) was isolated from the seeds of the fruits 
dried in the sun. This strain was identified as belonging to the genus Penicillium using Scanning Electron Microscope (SEM) methodology, based on the morphological structures.

The fungus was taxonomically assigned as Penicillium crustosum on the basis of the molecular techniques. The ITS sequence of the strain isolated in this study matched the ITS sequence of P. crustosum (GenBank Accession No GU723443), displaying 99\% similarity.

P. crustosum produced mycophenolic acid in the four treatments evaluated (A, B, C and D). However, in the treatments $\mathrm{B}$ and $\mathrm{C}$ in which acids were added, $P$. crustosum produced mycophenolic acid and 5-hydroxy-7-methoxy-4-methylphthalide (Figure 1).

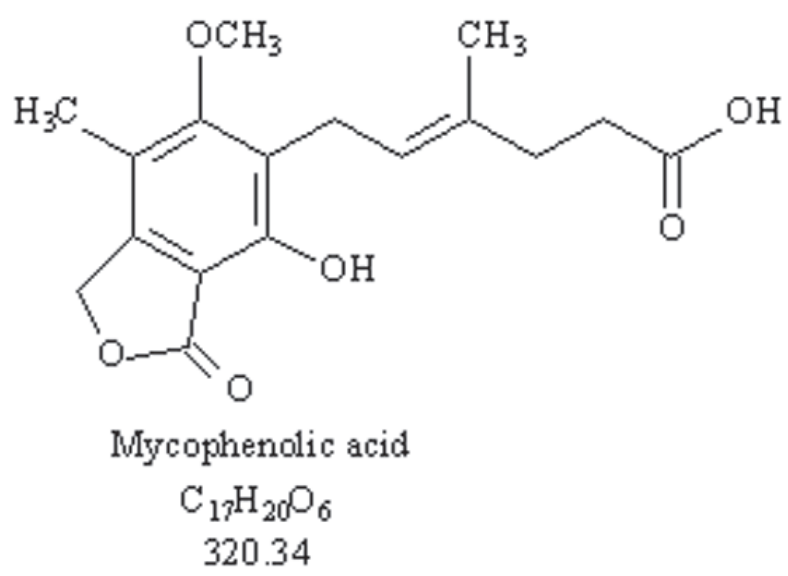

In treatment A (with no additional substances added) this fungus produced only mycophenolic acid $(102.0 \mathrm{mg})$ with a high degree of purity.

In the treatments in which organic acids were added (treatments $\mathrm{B}$ and $\mathrm{C}$ ), the biotransformation of the acids ( $\mathrm{B}$ - ferulic and quinic acids; $\mathrm{C}$ - cinnamic and 3,4-methylenedioxycinnamic acid) did not occur, as expected in this assay. The acids added to the culture medium were completely metabolized by the fungus, since these compounds were not detected in the fractions. However, two compounds were isolated, mycophenolic acid [B - 83.2 mg and C - 85.3 $\mathrm{mg}$ ] and 5-hydroxy-7-methoxy-4-methylphthalide [B - $22.3 \mathrm{mg}$ and C - $27.1 \mathrm{mg}$ ].

Mycophenolic acid was isolated in treatments $\mathrm{A}, \mathrm{B}$ and $\mathrm{C}$ due to its production in the fermentation<smiles>COc1cc(O)c(C)c2c1C(=O)OC2</smiles>

5-hydr oxy-7-methoxy-4-methylphtalide $\mathrm{C}_{10} \mathrm{H}_{10} \mathrm{O}_{4}$ 194.18

Figure 1 - Structures of the compounds mycophenolic acid and 5-hydroxy-7-methoxy-4-methylphthalide.

medium before supplementation with the acids. These results were confirmed by new cultures at several periods (Valente et al. 2007).

The synthesis of 5-hydroxy-7-methoxy-4methylptalide only occurred after the addition of the organic acids, since it was not isolated in treatment A. In experiment D (supplemented with caffeine), P. crustosun only produced mycophenolic acid $(3.25 \mathrm{mg})$, and the caffeine was completely recovered $(70.1 \mathrm{mg})$. This change in the metabolite produced in these treatments is probably related to the chemical composition of the culture medium, confirming the data in the literature that reports that the production of mycophenolic acid is highly dependent on the chemical composition of the culture medium, since there is no specific enzyme involved in the process (Demain 1968).

The characterization of the compounds produced by $P$. crustosun is described and discussed.

Mycophenolic acid is a white crystalline solid - chemical formula: $\mathrm{C}_{17} \mathrm{H}_{20} \mathrm{O}_{6}$, molecular weight (M.W.): 320.3, soluble in methanol and 
methylene chloride. The structure of the compound was determined by $1 \mathrm{D}\left({ }^{1} \mathrm{H}\right.$ and $\left.{ }^{13} \mathrm{C}\right)$ and $2 \mathrm{D}$ $\left({ }^{1} \mathrm{H}-{ }^{13} \mathrm{C}\right.$ gHMBC) NMR experiments (Table I) and confirmed by comparing the data with those from the literature (Rovirosa et al. 2006).

The ${ }^{1} \mathrm{H}$ NMR spectrum of the mycophenolic acid (Figure 2) showed signals for a methyl group at $\delta 1.78\left(\mathrm{H}^{-}{ }^{\prime}\right.$ ', singlet, $\left.3 \mathrm{H}\right)$ and a methyl group linked to aromatic ring at $\delta 2.13$ (H-9, singlet, $3 \mathrm{H})$, a signal for a methoxyl group at $\delta 3.74(\mathrm{H}-$ 8 , singlet, $3 \mathrm{H})$, two signals corresponding to aliphatic methylenes in the region of $\delta 2.47$ to $\delta$ 2.38 (H-3a' and H-3b', multiplet $2 \mathrm{H}$ ), of $\delta 2.32$ to $\delta 2.24$ (H-2', multiplet, $2 \mathrm{H})$, a broad doublet for a methylene group at $\delta 3.37(\mathrm{H}-6,2 \mathrm{H})$, a broad singlet at $\delta 5.18(\mathrm{H}-3,2 \mathrm{H})$ referring to an aliphatic methylene bearing oxygen, and a multiplet for a methyne group of $\delta 5.23$ to $\delta 5.28(\mathrm{H}-5,1 \mathrm{H})$.

In the MS/MS experiment (ESI - negative mode, with a collision energy of $5 \mathrm{eV}$ ) a fragment of $\mathrm{m} / z 319.3$ was obtained for the ion with a $\mathrm{m} / \mathrm{z}$ of 639.5. This fragment was exactly half of the mass, suggesting that the ion with a $\mathrm{m} / \mathrm{z}$ of 639.5 was formed by two molecules of mycophenolic acid linked by hydrogen bonds (dimmer), with lose a hydrogen $[\mathrm{H}+][\mathrm{M}+\mathrm{M}-\mathrm{H}]-$. The mass of $320.0 \mathrm{Da}$ was coherent with the NMR results. The MS/MS experiment for the ion with a $m / z$ of 319.3 showed the following fragments: $m / z \quad 191.1 \quad(100 \%)$, referring to the loss of a terpenic unit with a methyl arrangement; $m / z$ 275.3, referring to the loss of a carbon dioxide unit.

TABLE I

${ }^{1} \mathrm{H},{ }^{13} \mathrm{C}$ and $\mathrm{gHMBC}$ NMR data for the compounds mycophenolic acid and 5-hydroxy-7methoxy-4methylphthalide.

\begin{tabular}{|c|c|c|c|c|c|c|}
\hline \multirow[b]{2}{*}{ Position } & \multicolumn{3}{|c|}{ Mycophenolic acid } & \multicolumn{3}{|c|}{ 5-hydroxy-7methoxy-4methylphthalide } \\
\hline & $\delta^{13} \mathrm{C}$ & $\begin{array}{c}\delta^{1} \mathbf{H} \\
\text { (multiplicity, } J \text { in } \mathbf{H z} \text { ) }\end{array}$ & ${ }^{1} \mathrm{H}-{ }^{13} \mathrm{C}$ gНМBC * & $\delta{ }^{13} \mathrm{C}$ & $\begin{array}{c}\delta^{1} \mathbf{H} \\
\text { (multiplicity, } J \text { in } \mathbf{H z} \text { ) }\end{array}$ & ${ }^{1} \mathrm{H}-{ }^{13} \mathrm{C} g \mathrm{HMBC} *$ \\
\hline 1 & 173.0 & - & & 173.0 & - & - \\
\hline 3 & 70.0 & $5.18(2 \mathrm{H}, b r s)$ & $1 ; 3 \mathrm{a}$ & 68.0 & $5.15(2 \mathrm{H}$, br $s)$ & $1 ; 3 \mathrm{a} ; 4 ; 5 ; 7 ; 7 \mathrm{a}$ \\
\hline $3 a$ & 122.1 & - & - & 104.0 & - & - \\
\hline 4 & 116.7 & - & - & 110.0 & - & - \\
\hline 5 & 163.7 & - & - & 163.0 & - & - \\
\hline 6 & 106.4 & - & - & 98.0 & $6.49(1 \mathrm{H}, s)$ & $1 ; 4 ; 5 ; 7 ; 7 \mathrm{a}$ \\
\hline 7 & 153.7 & - & - & 158.0 & - & - \\
\hline $7 \mathrm{a}$ & 144.0 & - & - & 151.0 & - & - \\
\hline 8 & 61.0 & $3.74(3 \mathrm{H}, s)$ & 5 & 57.0 & $3.79(3 \mathrm{H}, s)$ & 7 \\
\hline 9 & 11.5 & $2.13(3 \mathrm{H}, s)$ & $3 ; 3 \mathrm{a} ; 4 ; 5$ & 11.0 & $1.95(3 \mathrm{H}, s)$ & $3 a ; 4 ; 5$ \\
\hline $\mathrm{OH}$ & - & $7.67(1 \mathrm{H}, b r s)$ & - & - & $10.59(1 \mathrm{H}, b r s)$ & $4 ; 6 ; 5$ \\
\hline 1 ' & 179.1 & - & - & - & - & - \\
\hline 2 ' & 32.7 & $2.38-2.47(2 \mathrm{H}, m)$ & $1^{\prime} ; 3^{\prime} ; 4^{\prime}$ & - & - & - \\
\hline 3 ' & 34.2 & $2.24-2.32(2 \mathrm{H}, m)$ & $1^{\prime} ; 2^{\prime} ; 4^{\prime} ; 5^{\prime} ; 7^{\prime}$ & - & - & - \\
\hline $4^{\prime}$ & 133.9 & - & - & - & - & - \\
\hline 5 , & 123.0 & $5.23-5.28(1 \mathrm{H}, m)$ & $3 ’ ; 7^{\prime}$ & - & - & - \\
\hline $6^{\prime}$ & 22.3 & $3.37(2 \mathrm{H}, b r d ; 6.8)$ & $5 ; 7 ; 5$ & - & - & - \\
\hline $7^{\prime}$ & 16.1 & $1.78(3 \mathrm{H}, s)$ & $3^{\prime} ; 4^{\prime} ; 5^{\prime}$ & & - & - \\
\hline
\end{tabular}

Abbreviations: $s$ - singlet, $b r s$ - broad singlet, $b r d$ - broad doublet, $m$ - multiplet.

* gHMBC data set: the numbers correspond to the correlated carbons. 


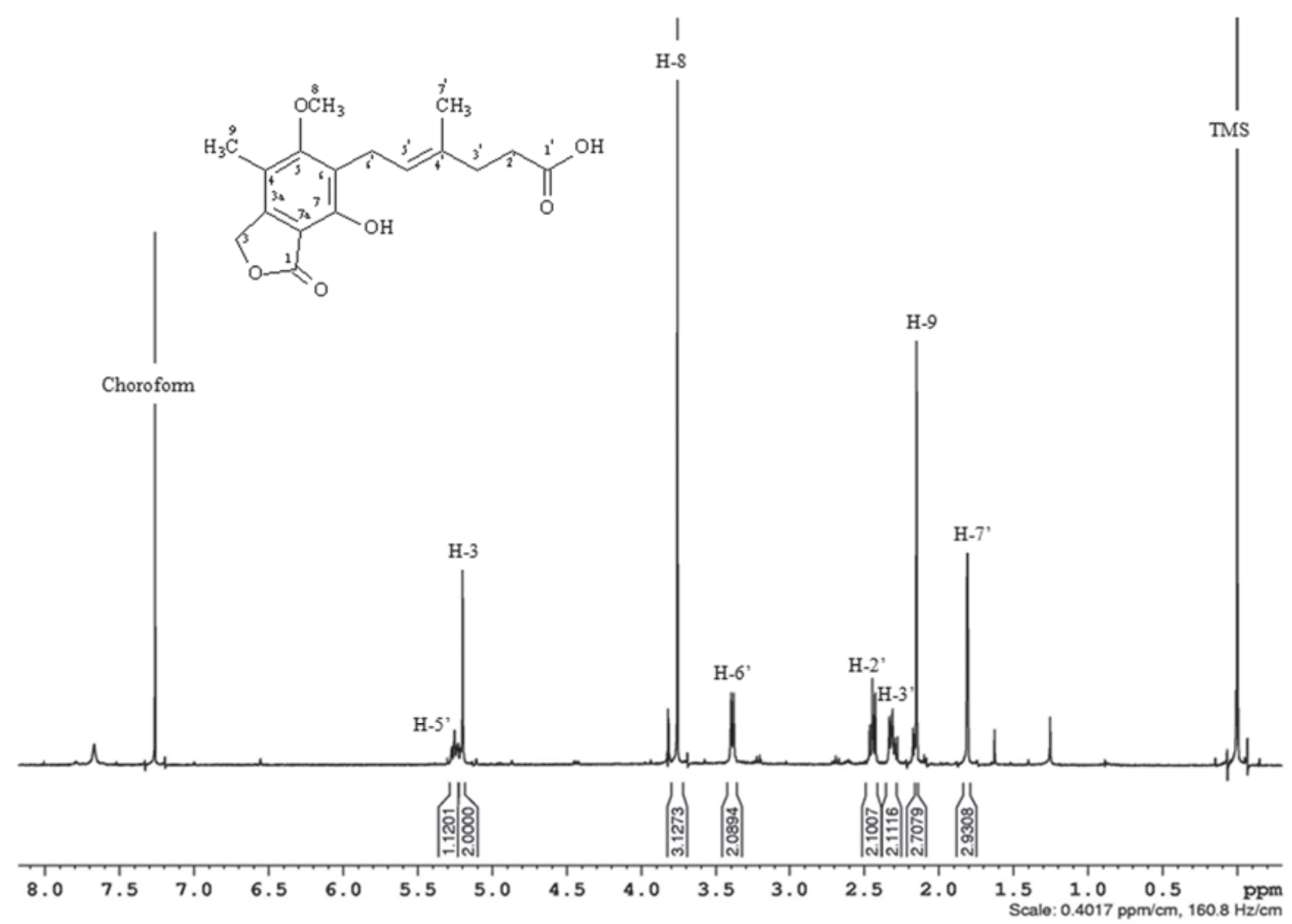

Figure $2-{ }^{1} \mathrm{H}$ NMR spectrum of mycophenolic acid $\left(400 \mathrm{MHz}, \mathrm{CDCl}_{3}\right)$.

5-hydroxy-7-methoxy-4-methylphthalide is a solid white powder - chemical formula: $\mathrm{C}_{10} \mathrm{H}_{10} \mathrm{O}_{4}$, molecularweight(M.W.): 194.0, solublein methanol and DMSO. The structure of the compound was determined by 1D and 2D NMR techniques (Table I) and confirmed by comparing the data with that of the NMR data for mycophenolic acid, especially using the $\mathrm{gHMBC}$ experiment.

The ${ }^{1} \mathrm{H}$ NMR spectrum of 5-hydroxy-7methoxy-4-methylphthalide (Figure 3) showed signals for methyl group at $\delta 1.95(\mathrm{H}-9$, singlet, $3 \mathrm{H})$, a signal for the methoxyl group at $\delta 3.79$ (H-8, singlet, $3 \mathrm{H}$ ), a signal corresponding to one methylene group at $\delta 5.15(\mathrm{H}-3$, singlet, $2 \mathrm{H})$, and a signal for aromatic hydrogen at $\delta 6.49$ (H-6, singlet, $1 \mathrm{H})$.

In the ${ }^{3} \mathrm{JCH}$ gHMBC experiment (Figure 4), $\mathrm{H}-3$ correlated with C3a $(\delta$ 104.0), C4 ( $\delta$ 110.0), C5 ( $\delta$ 163.0), C7 ( $\delta$ 158.0), C7a ( $\delta 151.0)$ and C1
( $\delta 173.0)$; H-6 correlated with $\mathrm{C} 1, \mathrm{C} 4, \mathrm{C} 5, \mathrm{C} 7$ and $\mathrm{C} 7 \mathrm{a}$; $\mathrm{H}-8$ correlated with $\mathrm{C} 3 \mathrm{a}, \mathrm{C} 4$ and $\mathrm{C} 5$ and $\mathrm{H}-9$ correlated with $\mathrm{C} 7$.

The mass spectrum (ESI - negative ion mode) of 5-hydroxy-7-methoxy-4-methylphthalide showed the $[\mathrm{M}-\mathrm{H}]^{-}$ion at $\mathrm{m} / \mathrm{z} 193.0$ and the chloride adduct $\left[\mathrm{M}+\mathrm{C}_{1}\right]^{-}$at $m / z$ 229.0. The mass spectrum (ESI positive ion mode) showed the $[\mathrm{M}+\mathrm{H}]^{+}$ion at $\mathrm{m} / \mathrm{z}$ 195.0. The MS data suggested that the molecular mass of the compound was $194 \mathrm{Da}$. In the MS/ MS experiment (ESI - negative mode) for the ion $\mathrm{m} / \mathrm{z} 193.0$ was obtained the fragment of $\mathrm{m} / \mathrm{z} 178.0$ $\left[\mathrm{M}-\mathrm{CH}_{3}\right]^{-}$.

Thus, 5-hydroxy-7-methoxy-4-methylphthalide was isolated for the first time. However, natural phthalidessuchas(5,7-dihydroxy-4-methylphthalide) and (5,7-dimethoxyisobenzofuran-1(3H)-one) have already been reported (Puel et al. 2005, Fujimoto et al. 1999, Habib et al. 2008, Sun et al. 2009). That 


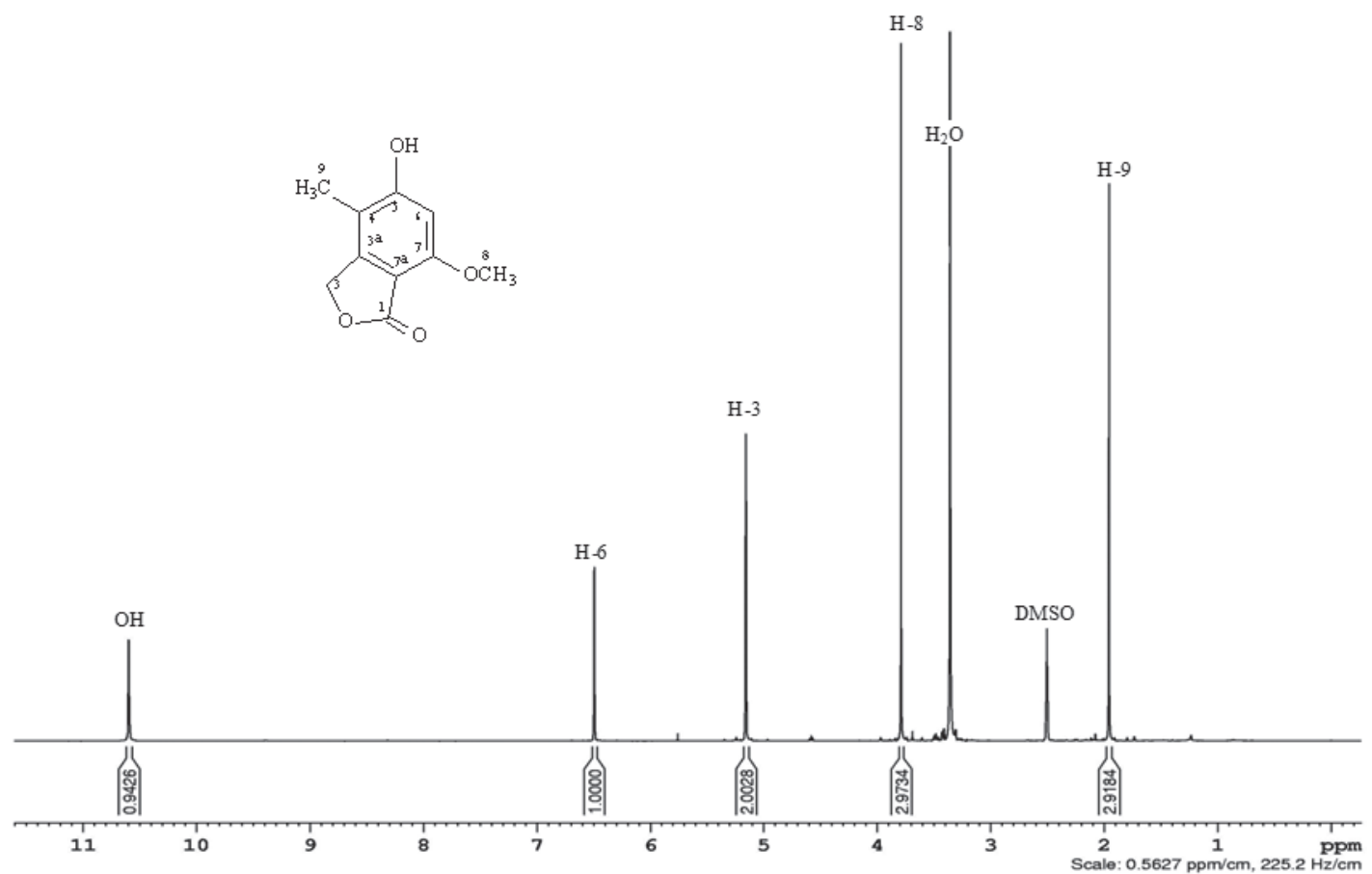

Figure 3 - ${ }^{1} \mathrm{H}$ NMR spectrum of 5-hydroxy-7-methoxy-4-methylphthalide (400 MHz, DMSO).

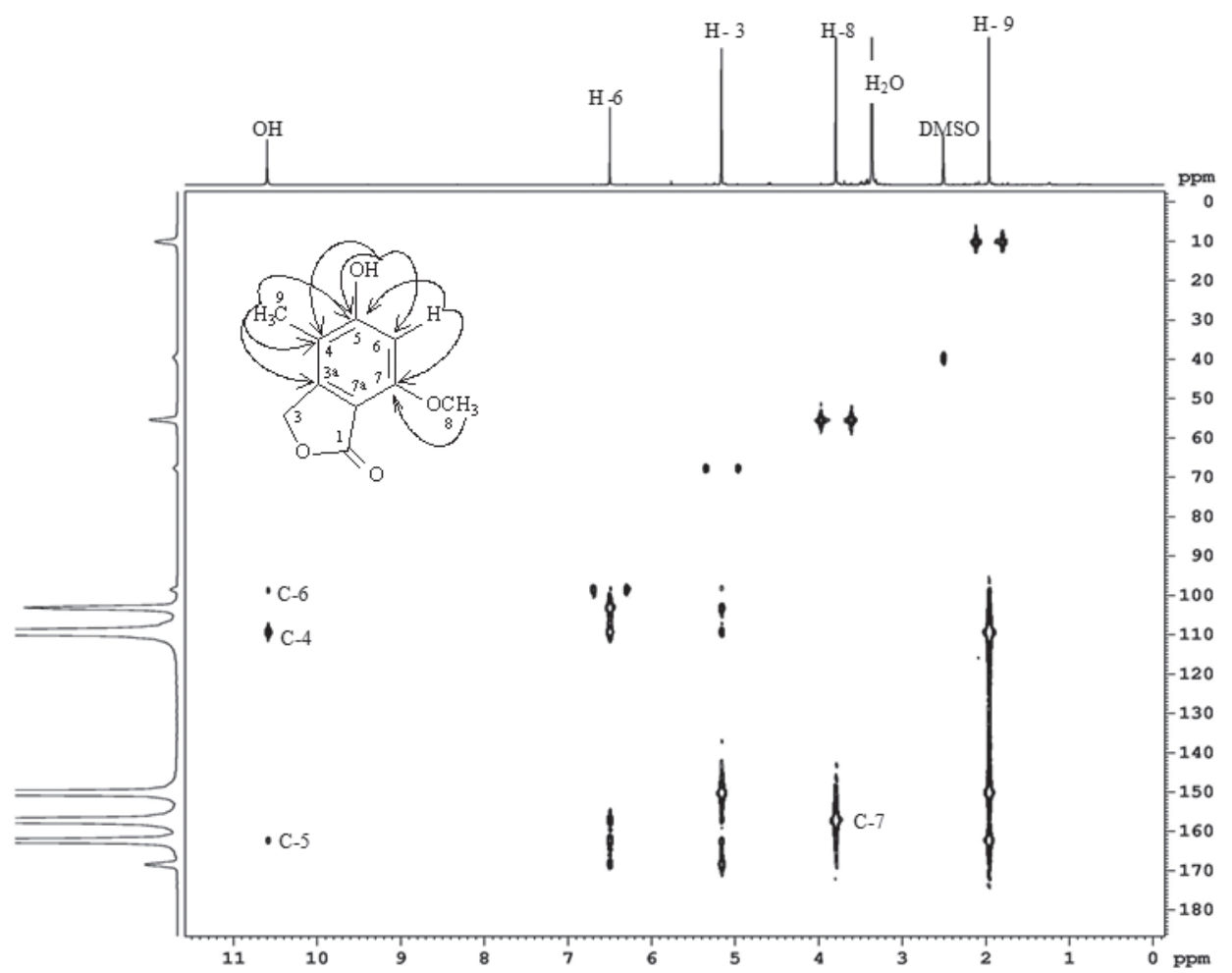

Figure 4 - gHMBC NMR experiment of 5-hydroxy-7-methoxy-4-methylphthalide (400 MHz, DMSO) and important long range correlations detected. 
compound could be used as an intermediate in the process of synthesizing some significant products, such as 5,7-dimethoxy-4-methylphthalide and 5,7-dihydroxy-4-methylphthalide (Zuo et al. 2008), or mycophenolic acid and its analogs (Lee et al. 2001).

From the results obtained, it was concluded that the production of mycophenolic acid was related to the acidic or basic nature of the substances added to the culture medium.

\section{ACKNOWLEDGMENTS}

The authors are thankful to the Coordenação de Aperfeiçoamento de Pessoal de Nível Superior (CAPES), the Conselho Nacional de Desenvolvimento Científico e Tecnológico (CNPq), the Fundação de Amparo à Pesquisa do Estado de São Paulo (FAPESP) and to the Financiadora de Estudos e Projetos (FINEP) for their financial support.

\section{RESUMO}

As reações químicas realizadas por microorganismos têm sido utilizadas como uma ferramenta na química moderna. Este artigo relata a produção de ácido micofenólico e uma nova ftalida pelo fungo endofítico Penicillium crustosum obtido a partir de grãos de café. O fungo foi cultivado em meio líquido durante um período de sete dias, e depois disso, o meio de cultura foi dividido em quatro lotes: A, B, C e D, nos quais diferentes substâncias orgânicas foram adicionadas. O lote A foi mantido como controle para avaliar a ocorrência de biotransformação. Os ácidos orgânicos foram adicionados ao meio de cultura dos lotes B (ácidos ferúlico e quínico) e C [ácido cinâmico e 3,4-(metilenodioxi) cinâmico], e cafeína foi adicionada ao lote D. Todos estes compostos orgânicos foram dissolvidos em DMSO, e a fermentação foi mantida por mais 13 dias, totalizando 20 dias. $\mathrm{O}$ ácido micofenólico foi isolado a partir da cultura sem adição de ácidos (lote A). O ácido micofenólico e uma nova ftalida, 5-hidroxi-7-metoxi-4-metilftalida, foram isolados a partir dos lotes B e C, e ácido micofenólico e cafeína (adicionada ao meio de cultura) foram isolados a partir do lote $\mathrm{D}$. As estruturas foram determinadas pela técnica de RMN e confirmadas pelas técnicas de MS e MS/MS.

Palavras-chaves: café, fungo endofítico, ácido micofenólico, Penicillium crustosum, 5-hidroxi-7-metoxi4-metilftalida.

\section{REFERENCES}

ARNOLD AE. 2007. Understanding the diversity of foliar endophytic fungi: progress, challenges, and frontiers. Fungal Biol Rev 21: 51-66.

BOAVENTURA MAD, LOPES RFAP AND TAKAHASHI JA. 2004. Microorganisms as tools in modern chemistry: the biotransformation of 3-indolylacetonitrile and tryptamine by fungi. Braz J Microbiol 35: 345-347.

DEMAIN AL. 1968. Regulatory mechanisms and the industrial production of microbial metabolites. Lloydia 31:395-418.

FuJimoto H, FuJimaki T, OKUYAMA E AND YAMAZAKI M. 1999. Immunomodulatory constituents from an ascomycete, Microascus tardifaciens. Chem Pharm Bull 47: 1426-1432.

GRINYO JM. 2001. Place of mycophenolate mofetil in renal transplantation. Transplant Proc 33: 997-999.

Habib E, Leo'n F, Bauer JD, Hill RA, Carvalho P, Cutler GH AND Cutler SJ. 2008. Mycophenolic Derivatives from Eupenicillium parvum. J Nat Prod 71: 1915-1918.

LeE Y, Fujiwara Y, Ujita K, Nagatomo M, OHata H and SHimizU I. 2001. Syntheses of mycophenolic acid and its analogs by palladium methodology. Bull Chem Soc Jpn 74: 1437-1443.

MELO IS AND FAULL JL. 2004. Scanning electron microscopy of conidia of Trichoderma stromaticum, a biocontrol agent of witches' broom disease of cocoa. Braz J Microbiol 35: 330-332.

Mitchell AM, Strobel GA, Hess WM, VArgas PN AND EZRA D. 2008. Muscodor crispans, a novel endophyte from Ananas ananassoides in the Bolivian Amazon. Fung Divers 31: 37-44.

Puel O, Tadrist S, Galtier P, Oswald IP And Delaforge M. 2005. Byssochlamys nivea as a source of mycophenolic acid. Appl Environ Microbiol 71: 550-553.

RAEDER U AND BRODA P. 1985. Rapid preparation of DNA from filamentous fungi. Lett Appl Microbiol 1: 17-20.

Rovirosa J, Diaz-Marrero A, Darias J, Painemal K AND SAN-MARTIN A. 2006. Secondary metabolites from marine Penicillium brevicompactum. J Chil Chem Soc 51(1): 775-778.

SCHMEDA-HIRSCHMANN G, ARANDA C, KURINA M, RODRÍGUEZ JA AND THEODULOZ C. 2007. Biotransformations of Imbricatolic Acid by Aspergillus niger and Rhizopus nigricans Cultures. Molecules 12: 1092-1100. 
SILVA HSA, BETTIOL W, TERRASAN CRF, TOZZI JPL, MELO IS AND NUNES FV. 2006. Microrganismos endofíticos: potencial de uso como agentes de biocontrole da ferrugem do cafeeiro. Boletim de Pesquisa e Desenvolvimento 38, EMBRAPA-CNPMA. http://ainfo.cnptia.embrapa.br/digital/ bitstream/CNPMA/7434/1/boletim_38.pdf

STROBEL G AND DAISY B. 2003. Bioprospecting for Microbial Endophytes and Their Natural Products. Mol Biol Rev 67: 491-502.

Sun MX, Li X, LIU WY And XiaO K. 2009. 5,7-Dimethoxyisobenzofuran-1(3H)-one. Acta Cryst E65: o2146.

Tamura K, Dudley J, Nei M AND Kumar SM. 2007. Molecular Evolutionary Genetics Analysis. Mol Biol Evol 24: 1596-1599.
VALENTE AMMP, BOFFo EF, Ferreira AG, Rodrigues Filho E, NAScimento RS, Silva JL, Vilela ESD AND MELO IS. 2007. Processo para produção e isolamento de ácido micofenólico e seus sais. UFSCAR; EMBRAPA. No: PI0704700-2. DEDF/INPI.

Vega FE, PAVA-RIPOll M, Posada F AND Buyer JS. 2005 Endophytic bacteria in Coffea arabica L. J Basic Microbiol 45: 371-380.

Vega FE AND Posada F. 2006. Penicillium species endophytic in coffee plants and ochratoxin A production. Mycologia 98: 31-42.

ZUO L, YAO SY AND DUAN WH. 2008. New synthetic methods of 5,7-dimethoxy-4 methylphthalide and 5,7-dihydroxy4-methylphthalide. Chin J Org Chem 28: 1982-1985. 